\title{
THE CONCEPT OF WIND FARMS LOCATION IN THE SIENIAWA PROTECTED LANDSCAPE AREA - THE ASSESSMENT OF THE CONDITIONS OF THE POSSIBILITIES
}

\author{
Jacek Rybarkiewicz ${ }^{凶}$ \\ Faculty of Architecture and Fine Arts, Krakow Academy of Andrzej Frycz Modrzewski in Krakow, Kraków
}

\begin{abstract}
The company WM Wiatrowiec Energie in recognition of favourable natural conditions and an agreement with the authorities of the city and commune Sieniawa initiated activities for the location of wind farms in the Sieniawa Protected Landscape Area (Sieniawski Obszar Chronionego Krajobrazu - SOChK). The planned implementation of the complex of 51 wind turbines required examining compliance with the formal and legal status of the area and the lack of cultural and ecological conflicts. The progressing, evaluative process of anthropogenic and cultural transformations, which has been ongoing since the establishment of the SOChK, as well as transformations associated with this ecosystem, have become an impulse for new research and a new look at the problem of landscape protection. The updated value of landscape and spatial arrangement of the city and commune Sieniawa conducted by the team of experts in the period from December 2009 to March 2011 , led to the assessment of the new conditions and the related legitimacy of the possible verification of the SOChK boundaries giving the opportunity to implement the subject undertaking. Simultaneously the expert team pointed out that during the establishment of protected landscape areas it is necessary to use more thorough and comprehensive studies than those that were the basis for the creation of SOChK.
\end{abstract}

Key words: landscape revitalisation, wind power industry

\section{INTRODUCTION}

In the realities of today's ecological, economic and general social conditions, there's no need to prove suitability to use non-emission, renewable energy sources. Each such possibility gives a chance to improve energy security in the whole dimension of supplementing resources and supporting ongoing processes of socioeconomic development.

In the name of such references, implementation proceedings for the development of the renewable energy technical base - regardless of business im- peratives - are justified, provided that they comply with the formal and legal status of the area and the lack of cultural and ecological conflicts. The deciding about the location of wind farms, apart from the positive assessment of the impact on the environment $^{1}$, are favourable ambient conditions, including the distance from buildings (at least $500 \mathrm{~m}$ ), from protected areas (including forests) and from good aerodynamic conditions (favourable wind conditions) and the absence of formal - planning conflicts especially in contact with natural and landscape values and resources.

\footnotetext{
${ }^{1}$ Wind farms are ecological so-called zero-emission source of energy - vide website www.oddzialywaniawiatrakow.pl.
} 
Rybarkiewicz, J. (2019). The concept of wind farms location in the Sieniawa Protected Landscape Area - the assessment of the conditions of the possibilities. Acta Sci. Pol. Architectura, 18 (3), 55-66. doi: 10.22630/ASPA.2019.18.3.35

Investment initiative of the company WM Wiatrowiec Energie ${ }^{2}$ implementing the development in the area of Sieniawa commune complex of 51 windmills (Fig. 1) located in location sets ${ }^{3}$ was based on conven- ient, confirmed by ecophysiographic studies ${ }^{4}$, natural conditions of the area and on favourable references of the local social environment represented by the city and commune authorities of the Sieniawa, motivated by not

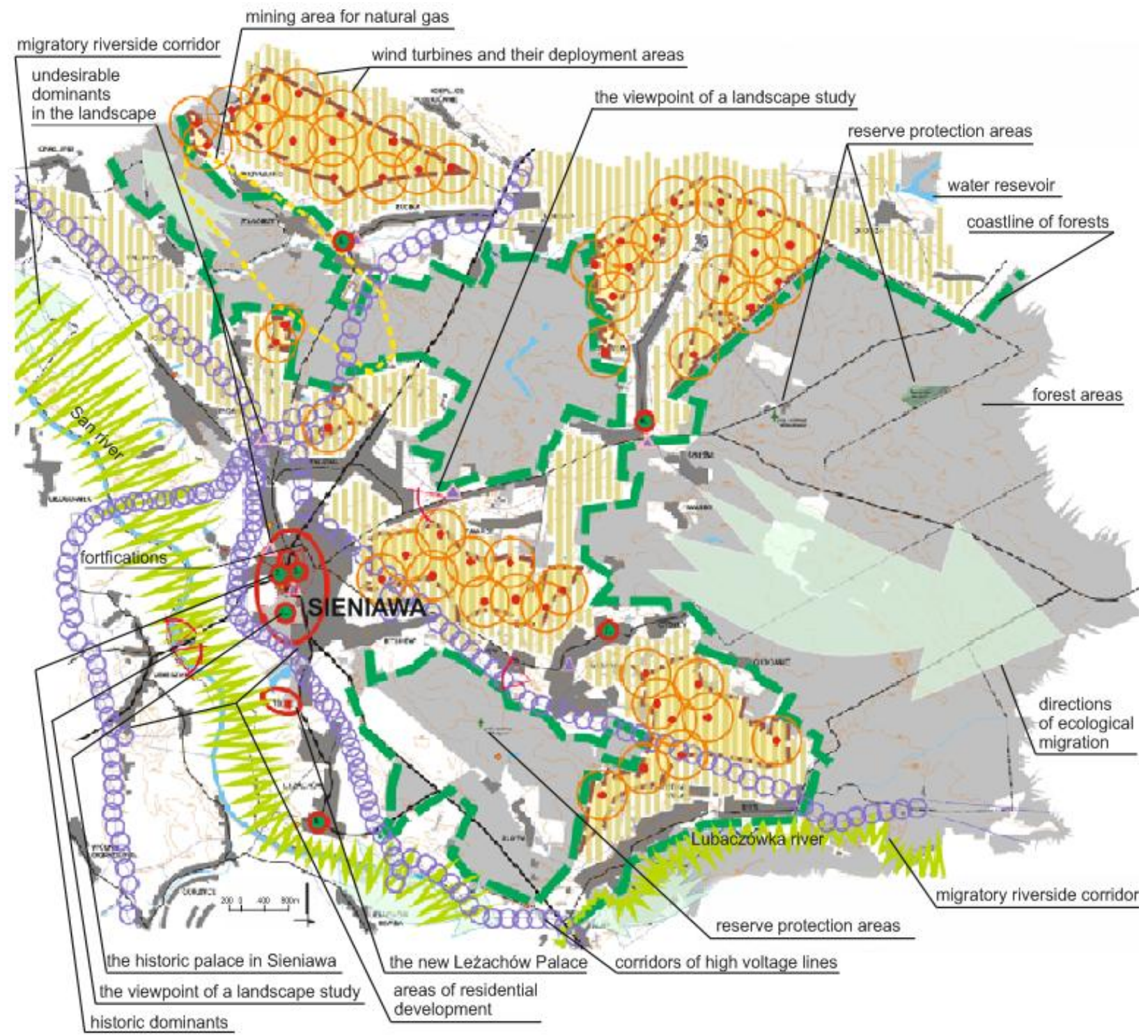

Fig. 1. Study of the distribution of planned wind farms in the context of areas with different landscape valorisation properties (own elaboration)

\footnotetext{
2 The company based in Warsaw, Marynarska 11.

${ }^{3}$ Preliminary technical documentation was prepared in 2009.

${ }^{4}$ The documentation was prepared by the Service Department of Physiology and Geology Engineering in Rzeszów in 2007.
} 
Rybarkiewicz, J. (2019). The concept of wind farms location in the Sieniawa Protected Landscape Area - the assessment of the conditions of the possibilities. Acta Sci. Pol. Architectura, 18 (3), 55-66. doi: 10.22630/ASPA.2019.18.3.35

only savings of local energy costs, but also opportunities to obtain new jobs for the local community.

In such a situation, due to the earlier creation of the Sieniawa Protected Landscape Area (Sieniawski Obszar Chronionego Krajobrazu - SOChK; Fig. 2), there was a need to recognize the existence or absence of hazards and limitation in the location of wind farms in the area of the commune, with particular reference to landscape ${ }^{6}$, natural and cultural values. The emerging doubts about formal and landscape conflicts related to the possibility of adverse environmental impact led to the necessity of detailed analyses estimating the level of these threats and the location contraindications arising from them not only for wind farms, but also other current local investment and economic initiatives.
Thus, there was a need to update the assessment of the natural and cultural values of the local landscape and possible verification of the spatial dependencies between this landscape components.

\section{METHOD OF CONDUCT}

The intention of the invited expert team was to make an objective and credible evaluation of the feasibility of the planned project, which using the tools of workshop of landscape design could be reliable.

The adopted method included:

- determination of the current formal status;

- update characterization and assessment of the current state;

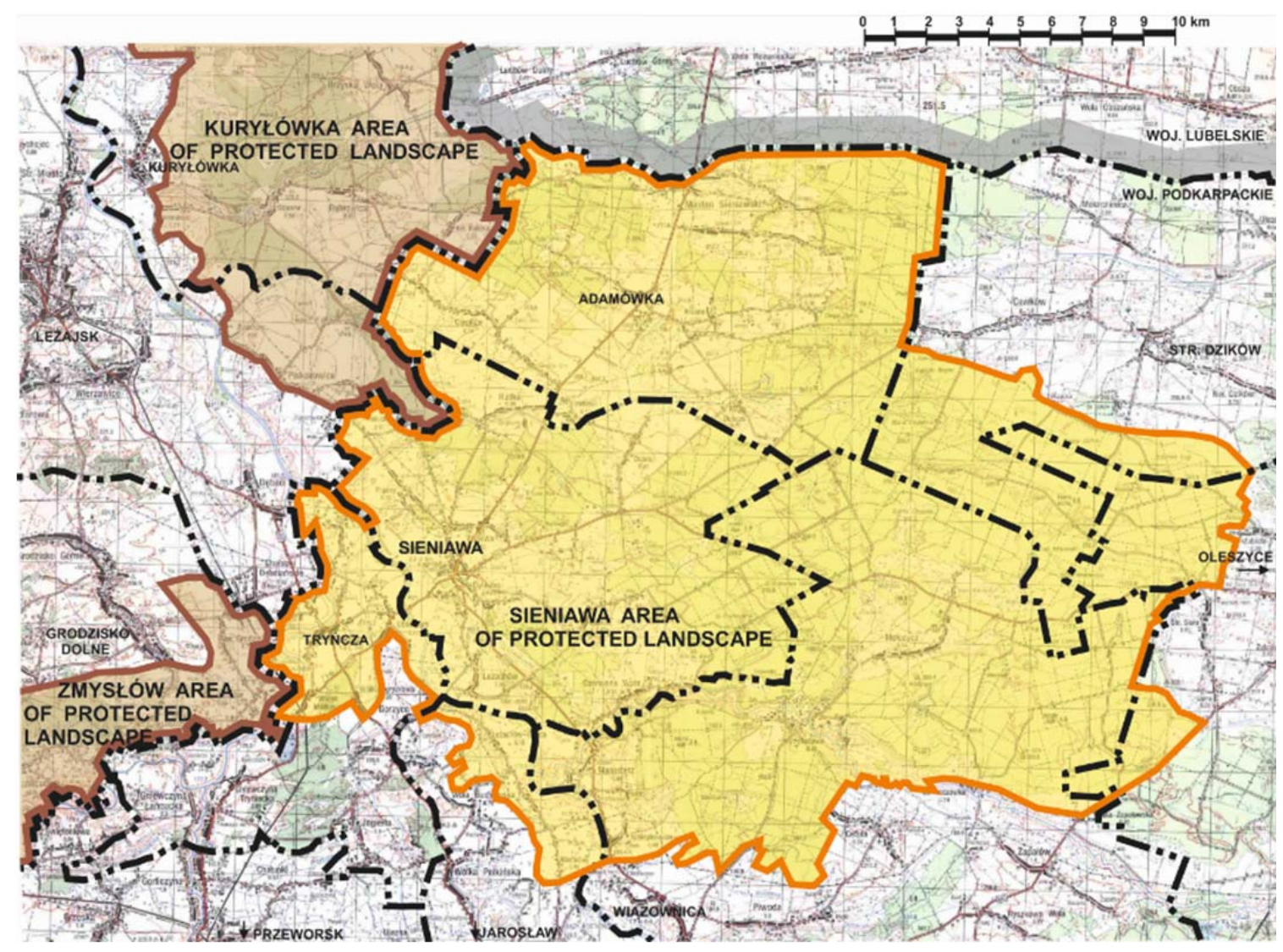

Fig. 2. The Sieniawa Protected Landscape Area - state 1986 (own elaboration)

\footnotetext{
${ }^{5}$ The will of the local social environment was part of the strategy of development of the city and the commune of Sieniawa for the years 2007-2013.

${ }^{6}$ The party establishing the status of the SOChK raised, among others, that the location of wind farms would degrade the visual quality of the natural and cultural landscape of Sieniawa and the newly created landscape compositions.
} 
- assessment of cultural and nature landscape value;

- studies of functional and compositional dependencies of the landscape;

- determination of flora and fauna habitat sites;

- delimitation of areas according to the criteria of revitalisation;

- detailed landscape inventories of wind farm location sites.

\section{THE FORMAL STATE AND CHARACTERISTICS OF THE FOUNDATIONS FOR THE ESTABLISHMENT OF THE SOChK}

The appointment of the SOChK took place on the basis of the Resolution of the Provincial National Council in Przemyśl No XX/148/87 of 25 June 1987 (31 years ago! $)^{7}$ maintained by subsequent legal acts, the last of which is Regulation No 66 of the Podkarpackie voivode of 28 June 2005 regarding the area of Sieniawa Protected Landscape Area, formalizing the behaviour of the boundaries of the SOChK area according to the original qualitative basis of its creation ${ }^{8}$.

The basis for the resolution adopted in 1987 was the project of the SOChK elaborated in 1986, whose modest scope (10 pages of typescript) included: a description of the boundaries and functional connections with the adjacent areas, including: natural, cultural and tourist values, development of the settlement network, characteristics of the areas proposed for inclusion in a higher form of protection and the usage structure of land (Biuro Urządzania Lasu i Geodezji Leśnej, Przemyśl, 1986).
The substantive scope included an assessment of the value of protected areas, not according to detailed kinds delimitation - distribution of natural and nonliving creatures, both individual specimens and their clusters, as well as communities in specific areas - but according to formal administrative boundaries. This had an impact on superficial evaluations and the lack of consequences of justifications that evaluating the quality of the assessment of protected areas, thereby thus impoverished the basics documenting landscape values and led to the perfunctory qualification of their protective safeguards.

\section{UPDATE CHARACTERISTICS AND OVERALL ASSESSMENT OF THE CURRENT STATE ${ }^{9}$}

The nearly 25 -year period that has elapsed since the SOChK was established has caused that references to the natural and landscape values of the area have become obsolete as a result of natural and cultural processes of ecosystem transformations ${ }^{10}$. There has also been a transformation of the material economic and utilitarian structure related to the ongoing changes in real operational needs (socio-economic conditions), which are included, i.a. in the priorities for obtaining financing ${ }^{11}$. All this leads to the commencement of new evaluations and, consequently, to the verification of the formal state of designation of areas of protection and qualification of acceptable activities.

On the little morphologically diverse area, whose amplitude of mild undulations is just over $50 \mathrm{~m}$, four

\footnotetext{
${ }^{7}$ The present three-tier administrative division of Poland, according to which the Sieniawa commune is located within the Podkarpackie voivodeship, has been in force since 1 January 1999.

${ }^{8}$ The area of the SOChK covers the whole area of the city and commune of Sieniawa, commune of Adamówka and about $50 \%$ of Tryńcza commune (Przeworsk county), fragment of Jarosław commune and about 50\% of Wiązownica commune (Jarosław county) and forest areas of Oleszyce and Stary Dzików communes (Lubaczów county).

${ }^{9}$ Due to the fact that the assessment of the conditions of the wind farm location possibility concerns the areas of the Sieniawa commune, the assessment of the current status covered by the expertise covers areas within the city limits and the Sieniawa commune with an indication of the legitimacy of making similar assessments for other areas included in the SOChK.

${ }^{10}$ Resulting among others from the progressing degradation of the environment and disturbances in the ecological system balance, including habitat transformations.

${ }^{11}$ Connected with the variability of the attractiveness of the recreational base and the possibilities of co-financing the recreation and tourist infrastructure.
} 
Rybarkiewicz, J. (2019). The concept of wind farms location in the Sieniawa Protected Landscape Area - the assessment of the conditions of the possibilities. Acta Sci. Pol. Architectura, 18 (3), 55-66. doi: 10.22630/ASPA.2019.18.3.35

types of cover can be distinguished: settlement areas, agricultural areas, floodplain terraces and forest areas. Each of these types is qualitatively subject to other transformation processes.

\section{Settlement areas}

The settlement system covers only approx. $10 \%$ of the commune area. It is characterized by deepening fragmentation and compositional mess.

The communication service consists of a system of provincial roads intersecting in the centre of Sieniawa (the city constitutes the largest settlement concentration of the commune) and combining the directions of connections with subregional centres and local roads serving subordinate villages (eight villages).

The dispersed spatial systems of the village, mostly surrounded by agricultural areas, stretch along roads. The concept of their functional and spatial composition - if it ever was - is now illegible, rather accidental as to the ordering rules: building lines, height proportions and shaping architectural and landscape interiors and directions of particular openings. This mess results in an excessive network of roads, which has a devastating effect on the environment and introduces chaos in the infrastructure network system (layout of high voltage power lines corridors - Fig. 1). There are scattered, single objects or several buildings, which deepen the chaos.

Within the village there are historic objects under the strict conservation protection zones - church complexes in the village of Leżachów (church from 1756), Rudka (church from 1693 and later a courtyard park from the 18th/19th century) and Dobra (an Orthodox church from 1880). The exhibition of these elements of the cultural landscape is local - it is located within the direct reception.

The main centre of cultural development of the area is the city of Sieniawa. Founded in 1672, it became the residence of the Sieniawski family, then one of the most powerful magnate families in south-eastern Poland ${ }^{12}$. This fact, however, did not result in the abundance of the material traces of this power. The oldest preserved relics come from a later period, from the second half of the 17th century: the town hall, an outline of the orthogonal construction of the urban layout and fragments of urban fortifications from 1664-1680. In the strict conservation zone A there are well-preserved sacred monuments: a Dominican monastery complex from 1719 and a parish church from 1753 and - a large magnate residence - a palace and park complex from 1720-1726, now adapted to the hotel functions (Fig. 3). The whole is located within

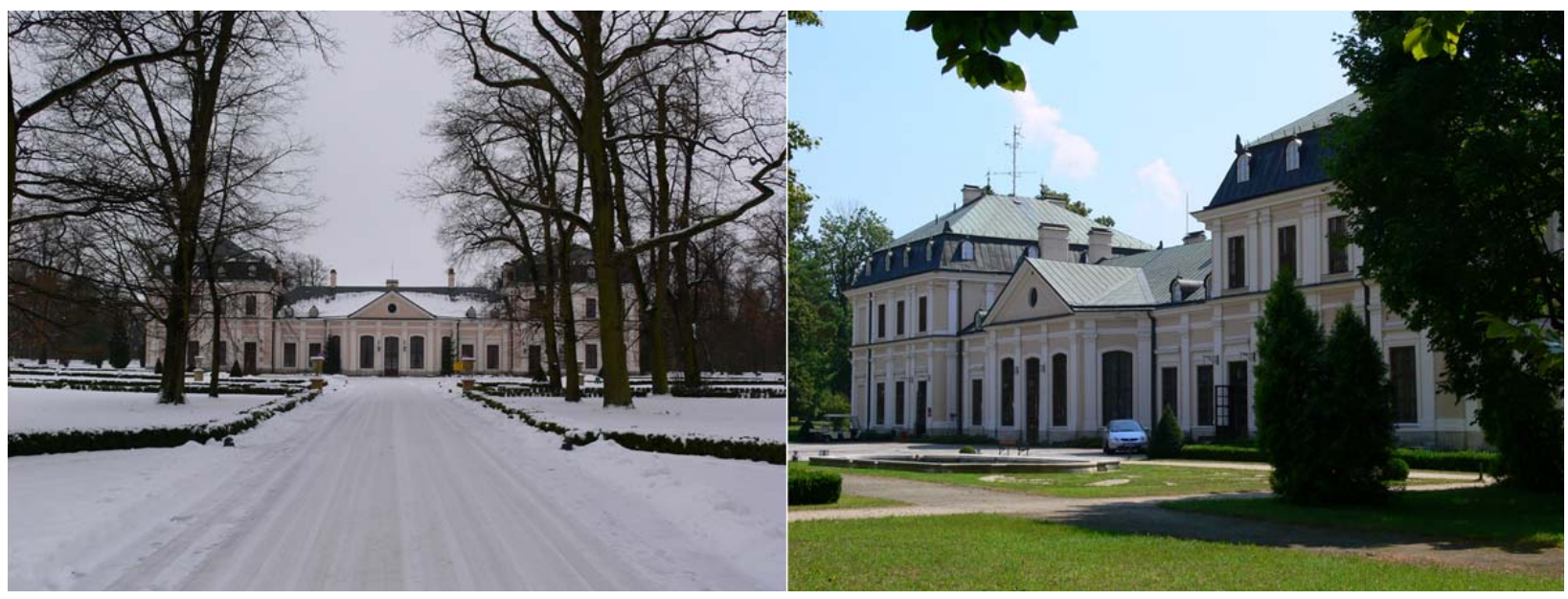

Fig. 3. Palace of the Sieniawski and the Czartoryski family in Sieniawa built in 1720-1726, currently adapted to the hotel (photo by Z. Konopka)

\footnotetext{
${ }^{12}$ The protoplast of the family was Mikołaj Sieniawski died in 1569 (Kuśnierz, 2001).
} 
Rybarkiewicz, J. (2019). The concept of wind farms location in the Sieniawa Protected Landscape Area - the assessment of the conditions of the possibilities. Acta Sci. Pol. Architectura, 18 (3), 55-66. doi: 10.22630/ASPA.2019.18.3.35

the historic urban complex of Sieniawa covered by the protection zone E - exhibition.

In the historical layout of the city are visible geometrical relationships between the three elements separately positioned fortifications (Fig. 4), which include: the city fortifications, bastion of the former fortifications, non-existent court and dominant on the hill above the town Dominican monastery of the Observants church. Outside the protection zone exposure, on the western side of the city (approx. $700 \mathrm{~m}$ from the market) is an old, decaying port granary of the 18th century ${ }^{13}$. Today, in the area of the storehouse are located brickworks and pumping equipment.
Important elements of the cultural landscape are the areas of cemeteries ${ }^{14}$ covered by the zone $\mathrm{K}$ and subject to the zones $\mathrm{W}$ - archaeological protection of archaeological sites ${ }^{15}$.

A new quality of identity is created by the monumental palace in Leżachów located on the western slope of Góra Kamieńska. This can be seen in the panoramic view from the bridge on the San river on the road leading from Przeworsk (Figs. 5, 6). Both the city's silhouette and the palace in Leżachów are an important value of the long-range landscape (Figs. 6, 7 - studies of functional and landscape dependencies and the possibilities of their modelling).

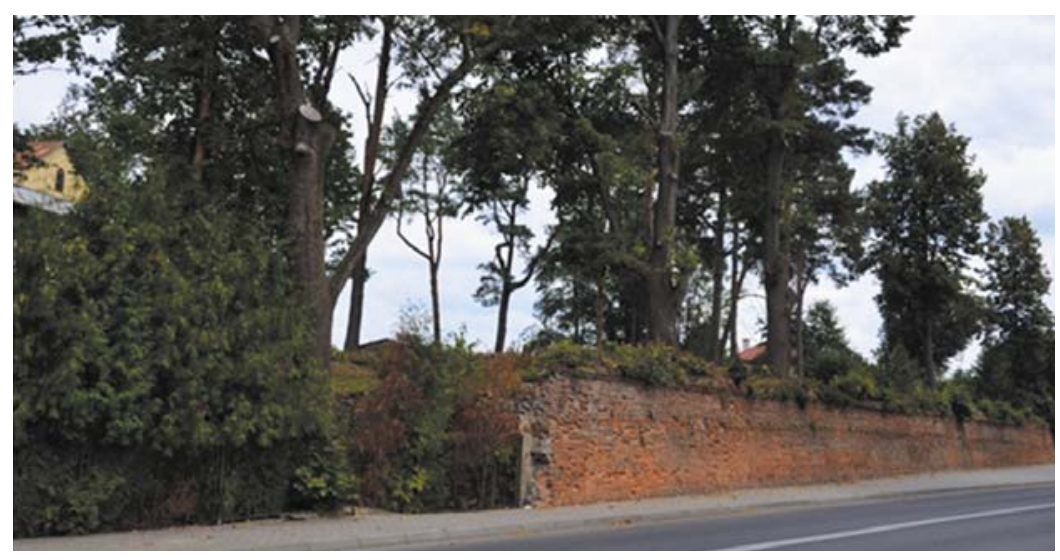

Fig. 4. Fragment of old town fortifications in Sieniawa from the mid-17th century (http://images.polskaniezwykla.pl/user/item/535402.jpg)

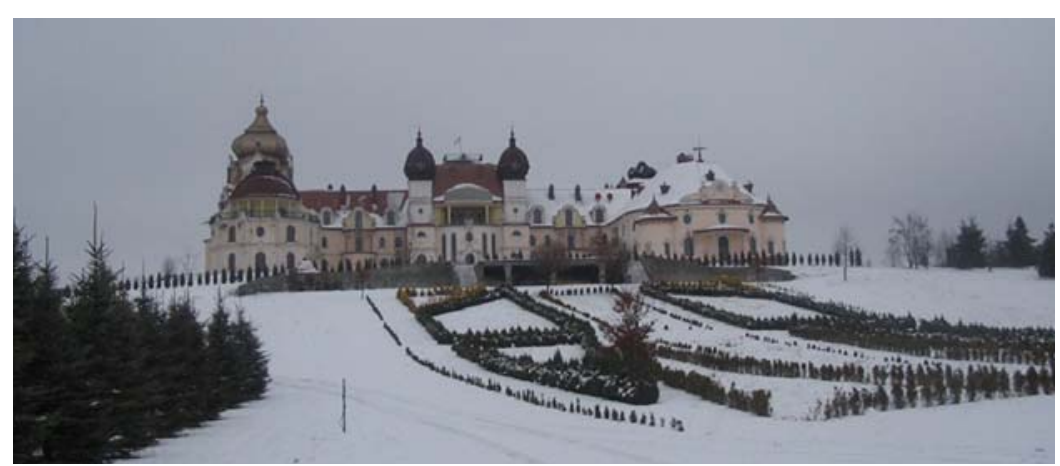

Fig. 5. New palace in Leżachów (photo by author)

\footnotetext{
${ }^{13}$ From the time when the San riverbed ran near the city.

${ }^{14}$ Cemeteries in Sieniawa, Leżachów, Rudka, Czerce, Pigany and Czerwona Wola.

${ }^{15}$ In the area of Sieniawa, Leżachów, Pigany, Czerwona Wola, Rudka and Paluchy settlement.
} 
Rybarkiewicz, J. (2019). The concept of wind farms location in the Sieniawa Protected Landscape Area - the assessment of the conditions of the possibilities. Acta Sci. Pol. Architectura, 18 (3), 55-66. doi: 10.22630/ASPA.2019.18.3.35

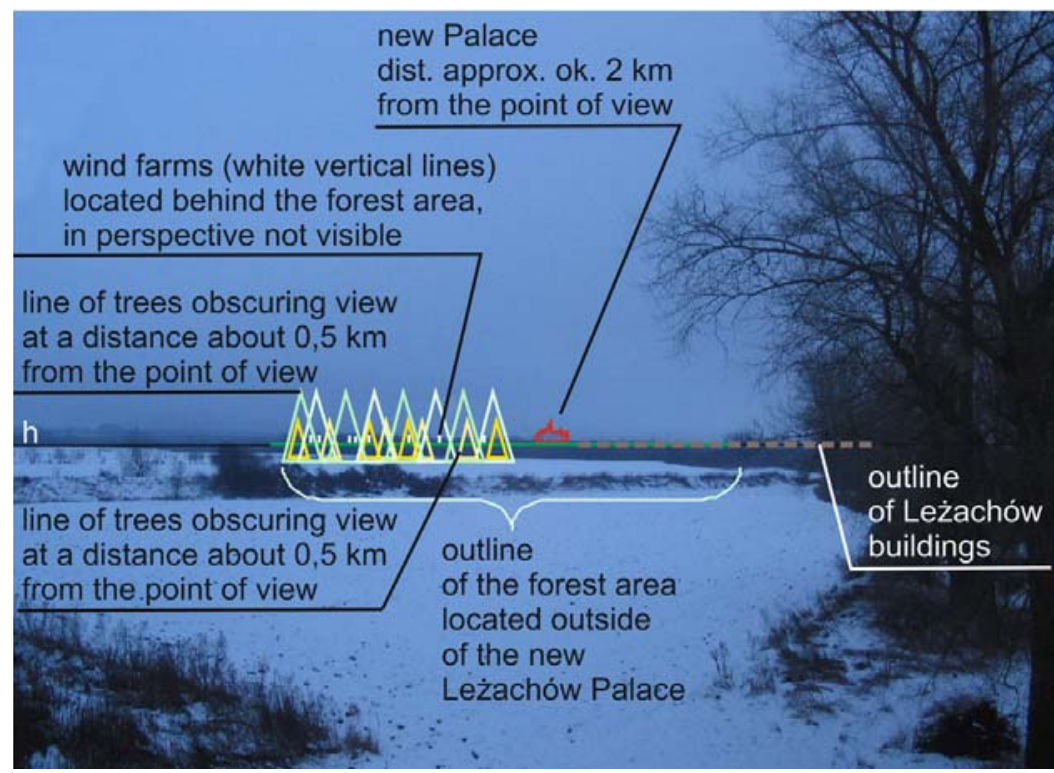

Fig. 6. Landscape study - view on new palace in Leżachów (own elaboration)

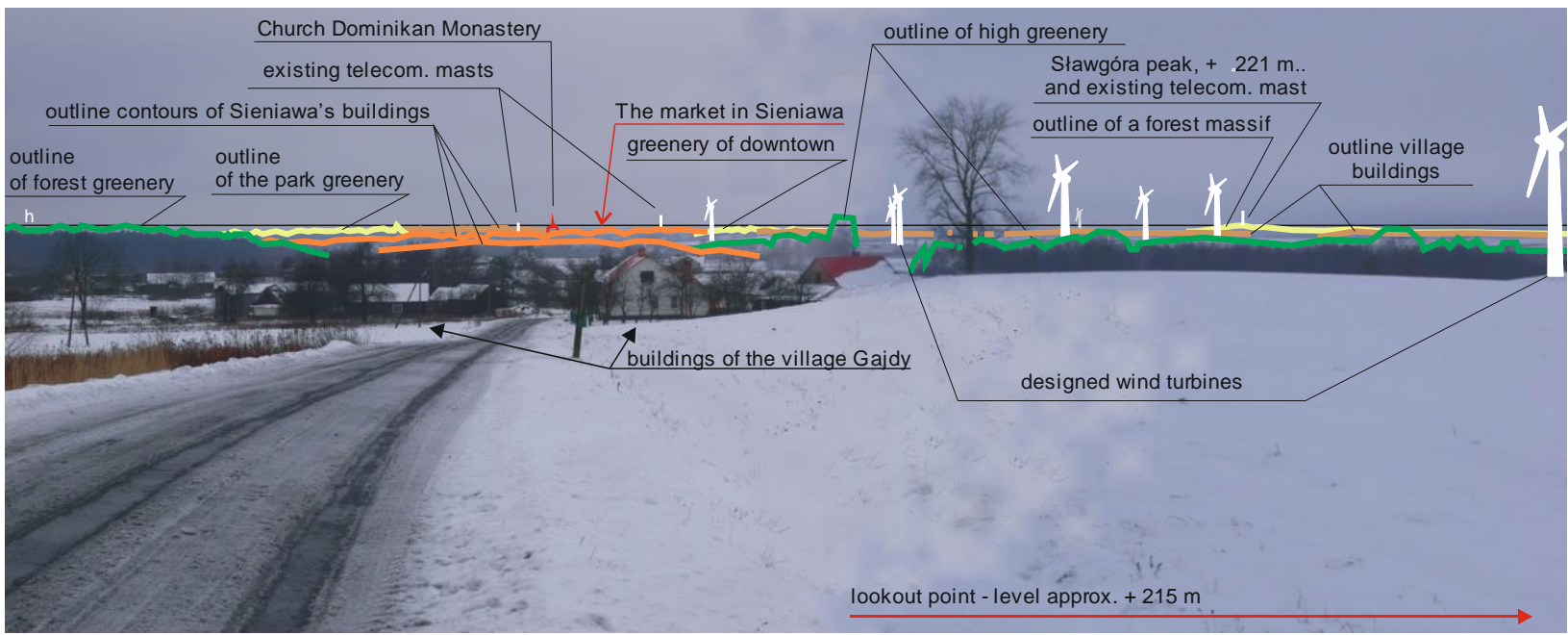

Fig. 7. Landscape study - view on Sieniawa (own elaboration)

\section{Agricultural areas}

Agricultural areas cover over $50 \%$ of the commune area. They are characterized by a very large fragmentation and resulting from the specificity of ownership divisions in the areas of south-eastern Poland, the banded shape of fields (length of $200-600 \mathrm{~m}$ at width of 20-60 m). The monocultural form of crops, despite their diversity, makes the most progressive process of environmental and landscape degradation noticeable here. Meridional intersections with furrows (balks) limit migration flows of plants, fungi and small animals, and are in conflict with the latitudinal course of ecological displacements. The diversity of crops and the individually independent (uncoordinated) way of running the economy on them determines the qualitative diversity of the natural landscape that goes beyond 
Rybarkiewicz, J. (2019). The concept of wind farms location in the Sieniawa Protected Landscape Area - the assessment of the conditions of the possibilities. Acta Sci. Pol. Architectura, 18 (3), 55-66. doi: 10.22630/ASPA.2019.18.3.35

the conditions of symbiosis with native components of ecosystems, their types, gatherings and focusing. This difference creates a difficult to define field of reference for the maintenance and restitution of nature and landscape values that motivate the earlier establishment of landscape protection for these areas of legal protection.

These conditions and the vastness of the area of agricultural areas make it possible to locate wind farms (Fig. 1 - wind farm distribution design). The way farms interact with the environment, including ornithophores, is comparable with other civilizational changes. It requires tedious, long-term research and constant monitoring and application of regulatory measures ${ }^{16}$.

\section{Riverside terraces}

The range of the riverside terrains of the San river valley is flooded. From the south it connects with the band trough picturesque of Lubaczówka river flows from forest areas.

Despite observation disturbances running parallel to the San river, the main, overhead power lines, these areas are characterized by properties with significant natural qualities. They should be absolutely qualified to be excluded from the location of wind farms.

\section{Forest areas}

Sieniawa Forests occupy less than $40 \%$ of the commune area. They are a remnant of the former Solska Forest. They are currently the largest forest complex occurring on the San river. They extend parallel to the rightbank by areas of the San river. They form a fragmented system of large forest patches in places. In the south-eastern part, these are water-bearing forests with reserve foci. In the north western part of the forest area is located in the mining area of natural gas.

In terms of natural values, forest areas are among the most valuable. Here, there are complexes of old-growth trees and other special nature reserves ${ }^{17}$ with rich flora, fauna, ornithofauna and chiropterofauna ${ }^{18}$. The values of these areas were just the basis for the formal establishment of protected landscape areas (Biuro Urządzania Lasu i Geodezji Leśnej, 1986). Tourist attractiveness of the commune area is based on the values of forest complexes. However, the infrastructure is poorly developed and there is no strategic concept for its development. Few recreational facilities are located mainly in the area of the Lubaczówka riverbed (Fig. 8), a tributary of the San river.

The potential for tourism development is based on the possibilities of local managements in areas outside the areas foreseen for the location of wind farms.

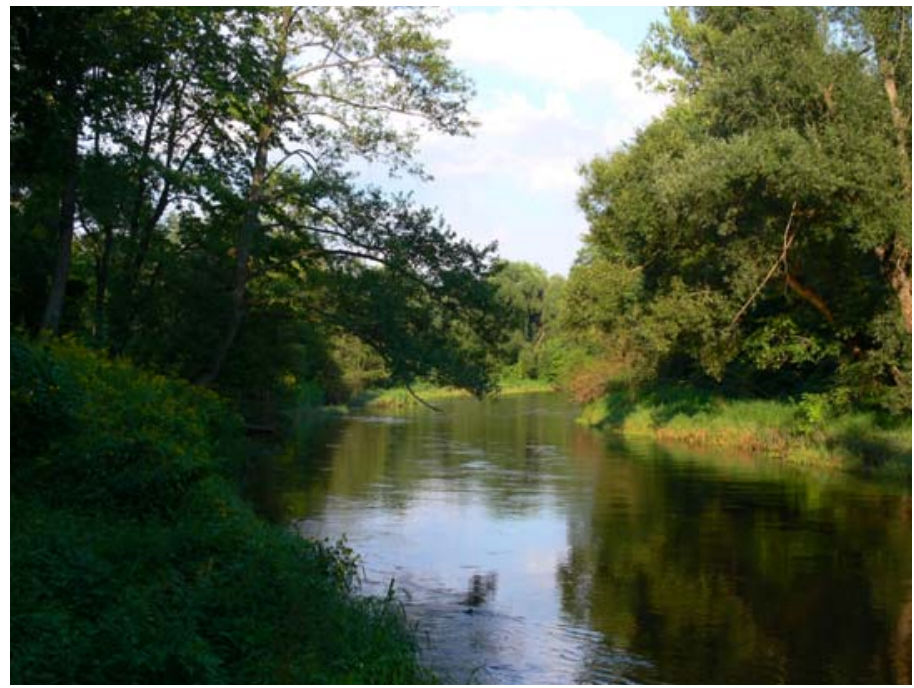

Fig. 8. Landscape of Lubaczówka river (photo by Z. Konopka)

\footnotetext{
${ }^{16}$ One of the problems is to determine the impact of wind farms on birds, including systems to deter birds and bats from colliding with windmill wings. Research shows that the level of harmfulness is still lower than the effect of other types of human economic activity, such as the development of communication, agriculture, energy networks or urbanisation. More information about the problem provides a rich bibliography (74 items) of Wuczyński (e.g. Wuczyński, 2009).

${ }^{17}$ Reserve Lupa and designed reserves Głażyna and Witoldówka and the charming reserves Kot and Ścieżki.

${ }^{18}$ Habitats of animals: wolf, deer, beaver, wild cat and otter, and birds: eagle, black stork, eagle owl, corncrake, hoopoe, flycatcher, and bats: myotis and nyctalus.
} 
Located within the north-western area of the forests (in the vicinity of Rudka village), the mining area of natural gas does not constitute an adverse impact on nature of areas eligible for landscape protection $^{19}$.

\section{SUMMARY}

The detailed characteristics of the landscape features of the Sieniawa commune and related valorisation attributes drawn up as part of the commissioned "Expert opinion on landscape and spatial conditions for implementation of wind farms in the Sieniawa Protected Landscape Area" 20 showed the extermination of the assessments constituting the basis for the creation of the SOChK. The generalization of administrative boundaries of landscape values was the basis for passive, conservative protection. This obscured the extremely diverse degree of value of the SOChK areas, where alongside areas with unique values (natural monuments, habitat and reserve areas, ecological migration corridors) there are areas with far advanced and progressive anthropogenic and cultural transformation processes. It made it difficult and prolonged the procedures, sometimes necessary and servile landscape, activities.

Assessment of landscape values according to the types of coverage and use of areas allows, according to the team of experts, to specify the manner of protection through the delimitation of areas with outstanding landscape values (including zones of their immediate environment) from areas with average landscape values or lack of values. This makes it legitimate to verify the boundaries, giving each of the delimited areas a management and use status appropriate to their internal conditions (Figs. 9, 10).

Settlement areas with far advanced and progressive anthropogenic and cultural transformation processes do not have to be protected by additional legal regulations because they have sufficient protection and protection of essential cultural and natural landscape values within separate, existing and binding formal and legal regulations. These and areas with average landscape values would therefore be exempted from the SOChK area, and the concept of location of wind farms within Sieniawa commune would be consistent with the possibilities of operations according to ordinary investment proceedings, because the existing legal status ${ }^{21}$ does not exclude these locations while maintaining the principle that despite the fact that such investments belong to a group that may have an impact on the environment, they will not significantly adversely affect its landscape.

According to the expert team, only areas with qualifications of clearly documented landscape assets should be subject to restrictions on all investment activities, except for those that would serve only protection, including investments creating landscape values of the area.

\footnotetext{
${ }^{19}$ Report on environmental impacts to the Resolution on the Spatial Development Plan No 8/07 Rudka.

${ }^{20}$ The study by Jacek Rybarkiewicz and Zygmunt Konopka, December 2009, Vol. I, p. 38 and three graphic attachments, "Update of natural and landscape-spatial values of the city and commune of Sieniawa for the purpose of verifying the boundaries of the Sieniawa Protected Landscape Area (expert assessment)", authors as above in cooperation with Zenon Szkamruk, December 2010, Vol. II, p. 64, including five map graphic studies, "An update of natural, landscape and spatial values of the city and commune of Sieniawa for the purpose of verifying the boundaries of the Sieniawa Protected Landscape Area - annex (expert assessment)", authors as above, March 2011, Vol. III, p. 89, including one map graphic design. The graphic part contains rich photographic documentation of landscape areas and flora and fauna, as well as map studies on 1:10000 and 1:50 000 scale including: studies of the spatial and functional areas and delimitation of areas with different landscape values, landscape analyses of individual wind farm locations, verification study of the SOChK boundaries according to the current (expert) assessment of natural and spatial values, landscape guidelines for the planned wind farms.

${ }^{21}$ Article 24 paragraph 1 point 2 of the Act of 16 April 2004 on nature conservation, updated on the occasion of the adoption of the Act of 3 October 2008 on the provision of information about the environment and its protection, public participation in environmental protection and environmental impact assessments.
} 
Rybarkiewicz, J. (2019). The concept of wind farms location in the Sieniawa Protected Landscape Area - the assessment of the conditions of the possibilities. Acta Sci. Pol. Architectura, 18 (3), 55-66. doi: 10.22630/ASPA.2019.18.3.35

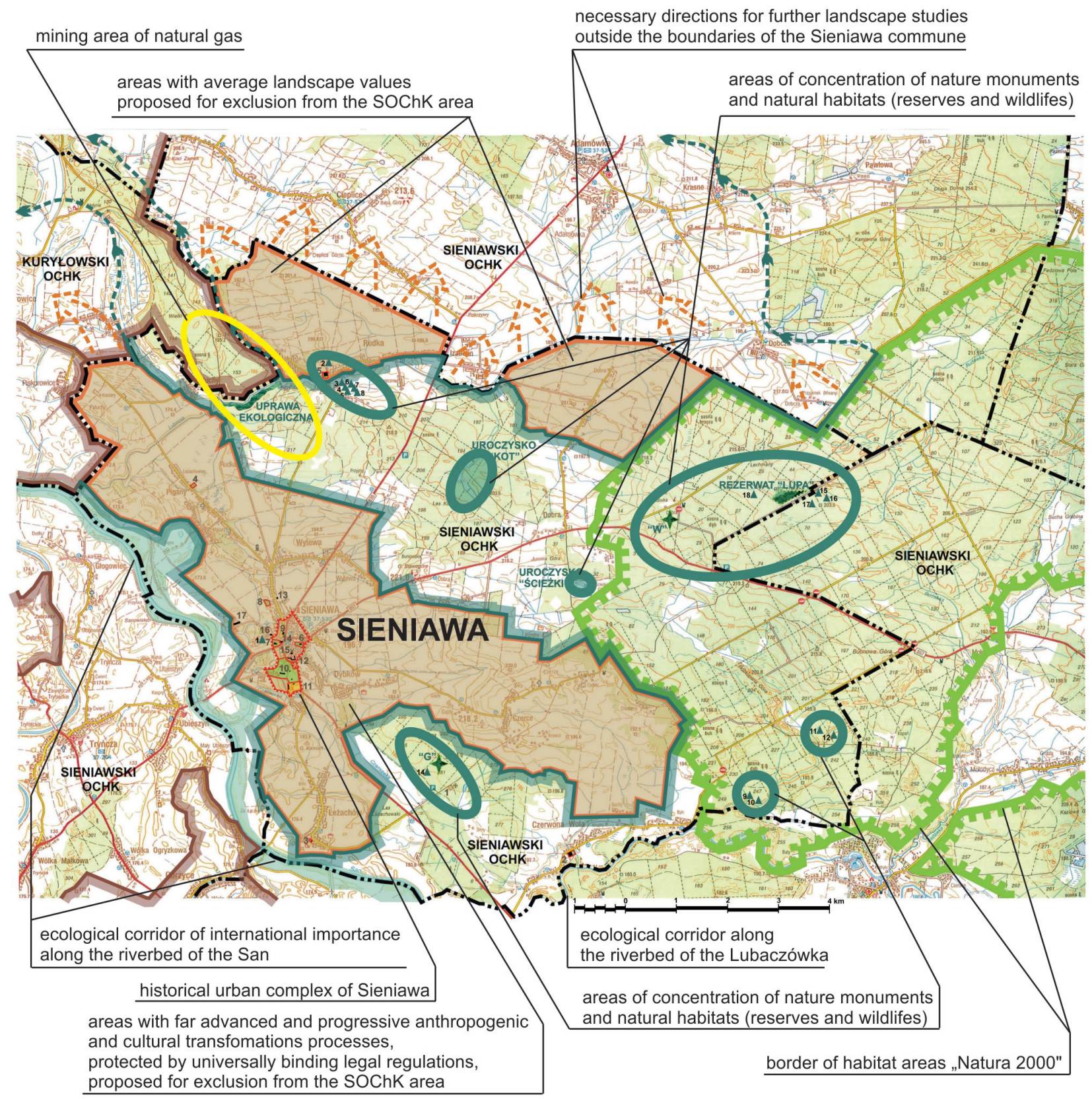

Fig. 9. Study verification borders of the Sieniawa Protected Landscape Area according to an updated assessment of natural and spatial values of the city and commune of Sieniawa (own elaboration) 
Rybarkiewicz, J. (2019). The concept of wind farms location in the Sieniawa Protected Landscape Area - the assessment of the conditions of the possibilities. Acta Sci. Pol. Architectura, 18 (3), 55-66. doi: 10.22630/ASPA.2019.18.3.35

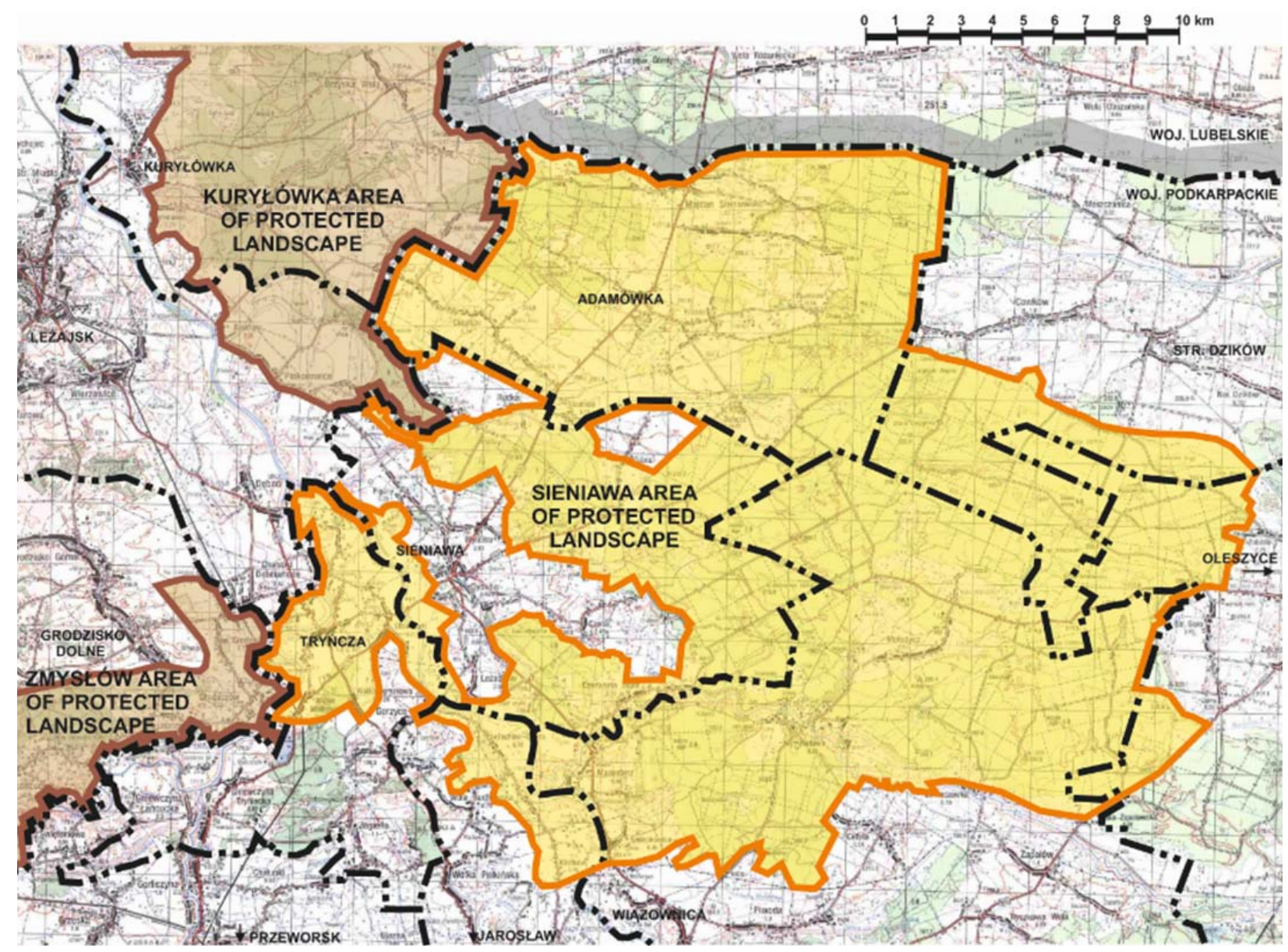

Fig. 10. Project of borders verification of the Sieniawa Protected Landscape Area (own elaboration)

This approach allows creative protection methods based on:

- channelling and modelling migration routes susceptible nature;

- separating and securing of the fields of visual and migrational opening;

- introduction of natural or technical barriers to prevent unwanted impacts;

- developing of utility infrastructure supporting protective measures;

- improving landscape management possibility;

- constant monitoring of impacts and focusing them on landscape-valuable places, habitats and areas;
- application of the diversity of landscape protection and care criteria adapted to the properties of landscape forms with the possibility of heuristic treatment of landscape beauty (Rostański, 2018);

- provoking holistic thinking that triggers the aspects of creative versatility and the use of bionic references to the harmony of nature in shaping the landscape $^{22}$.

The landscape studies carried out as part of the study were an attempt to show the practical possibilities of coordinating protective measures that do not limit infrastructural investments with a potential easement towards landscape values.

\footnotetext{
22 "thinking combining natural, physical and mathematical, psychological, sociological and philosophical ranges" (Dreszer \& Waligórska-Olejniczak, 2017).
} 
Rybarkiewicz, J. (2019). The concept of wind farms location in the Sieniawa Protected Landscape Area - the assessment of the conditions of the possibilities. Acta Sci. Pol. Architectura, 18 (3), 55-66. doi: 10.22630/ASPA.2019.18.3.35

\section{REFERENCES}

Biuro Urządzania Lasu i Geodezji Leśnej, Przemyśl (1986). Dokumentacja systemu obszarów chronionego krajobrazu województwa przemyskiego [Documentation of the system of protected landscape areas of the province of Przemyśl]. Przemyśl.

Dreszer, W. \& Waligórska-Olejniczak, B. (2017). Od bioniki do krajobrazu: Włodzimierza Dreszera refleksje nad dydaktyka artystyczna [From bionics to the landscape: Wtodzimierz Dreszer's thoughts on didactics of art]. Poznań: Uniwersytet Artystyczny w Poznaniu.

Kuśnierz, K. (2001). Sieniawa. Kraków: Wydawnictwo Politechniki Krakowskiej.

Rostański, K. M. (2018). Konotacje w architekturze, część 1. O sztuce wiązania znaczeń czerpanych z kultury [Connotations in architecture - part 1. On the art of observation of associations drawn from culture]. Gliwice: Wydawnictwo Politechniki Śląskiej.

Rozporządzenie nr 66 Wojewody Podkarpackiego z dnia 28 czerwca 2005 r. w sprawie Sieniawskiego Obszaru Chronionego. Dz. Urz. Woj. Podkarpackiego 2005 nr 94, poz. 1586 z późn. zm. [Regulation No 66 of the Podkarpackie voivode of 28 June 2005 regarding the area of Sieniawa Protected Landscape Area. Journal of the Podkarpackie voivodeship 2005 No 94, item 1586, as amended].

Uchwała nr L/496/10 Rady Miejskiej w Sieniawie z dnia 29 października 2010 r. w sprawie uchwalenia miejscowego planu zagospodarowania przestrzennego „Nr 8/07
Rudka”. Dz. Urz. Woj. Podkarpackiego 2010 nr 139, poz. 2896 [Resolution No L/496/10 Sieniawa City Council of 29 October 2010 on the spatial development plan "No 8/07 Rudka". Journal of the Podkarpackie voivodeship 2010 No 139, item 2896].

Uchwała nr XX/148/87 Wojewódzkiej Rady Narodowej w Przemyślu z dnia 25 czerwca 1987 r. sprawie szczegółowego zasięgu granic oraz zasad zagospodarowania obszarów chronionego krajobrazu na terenie województwa przemyskiego. Dz. Urz. Woj. Przemyskiego 1987 nr 8, poz. 92 [Resolution No XX/148/87of the Provincial National Council in Przemyśl of 25 June 1987 on the detailed range of borders and rules for the management of protected landscape areas in the Przemyśl voivodeship. Journal of the Przemyskie voivodeship 1987 No 8, item 92].

Ustawa z dnia 16 kwietnia 2004 r. o ochronie przyrody. Dz.U. $2004 \mathrm{nr}$ 92, poz. 880 [Act of 16 April 2004 on nature conservation. Journal of Laws 2004 No 92, item 880].

Ustawa z dnia 3 października 2008 r. o udostępnianiu informacji o środowisku i jego ochronie, udziale społeczeństwa w ochronie środowiska oraz o ocenach oddziaływania na środowisko. Dz.U. 2008 nr 199, poz. 1227 [Act of 3 October 2008 on the provision of information about the environment and its protection, public participation in environmental protection and environmental impact assessments. Journal of Laws 2008 No 199, item 1227].

Wuczyński, A. (2009). Wpływ farm wiatrowych na ptaki. Rodzaje oddziaływań, ich znaczenie dla populacji ptasich i praktyka badań w Polsce [The influence of wind farms on birds]. Notatki Ornitologiczne, 50, 206-227.

\section{KONCEPCJA LOKALIZACJI FARM WIATROWYCH NA TERENIE SIENIAWSKIEGO OBSZARU CHRONIONEGO KRAJOBRAZU - OCENA UWARUNKOWAŃ MOŻLIWOŚCI}

\section{STRESZCZENIE}

Firma WM Wiatrowiec Energie w uznaniu dogodnych warunków naturalnych i w porozumieniu z władzami Miasta i Gminy Sieniawa wszczęła działania na rzecz lokalizacji farm wiatrowych na terenie powołanego w 1986 r. Sieniawskiego Obszaru Chronionego Krajobrazu (SOChK). Planowane zagospodarowanie kompleksu 51 wiatraków wymagało zbadania zgodności ze stanem formalnoprawnym obszaru i brakiem konfliktów kulturowo-ekologicznych. Trwający od czasu powołania SOChK, postępujący, dewaluacyjny proces przekształceń antropogenicznych i kulturowych oraz związane z tym przekształcenia ekosystemowe stały się impulsem dla nowych badań i nowego spojrzenia na problem ochrony krajobrazu. Przeprowadzone przez autorski zespół ekspercki od grudnia 2009 do marca 2011 roku aktualizacje waloryzacyjne przyrodniczo-krajobrazowo-przestrzenne Miasta i Gminy Sieniawa prowadziły do oceny nowych uwarunkowań i związanej z tym zasadności ewentualnej weryfikacji granic SOChK, dającej możliwość realizacji przedmiotowego przedsięwzięcia. Jednocześnie zespół ekspercki zwrócił uwagę, że przy okazji ustanawiania obszarów chronionego krajobrazu niezbędne jest stosowanie bardziej wnikliwych i wszechstronnych badań niż te, które były podstawą utworzenia SOChK.

Słowa kluczowe: waloryzacja krajobrazu, energetyka wiatrowa 